\title{
Evaluation of residual tumors and recurrence rates of malignant melanoma and non-melanoma skin cancer of head and neck region
}

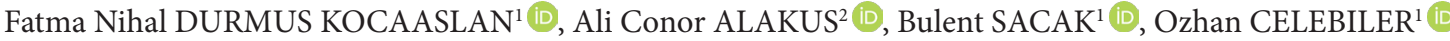 \\ 1 Department of Plastic, Reconstructive and Aesthetic Surgery, School of Medicine, Marmara University Training and Research Hospital, Pendik, \\ Istanbul, Turkey \\ 2 Department of Maxillofacial Surgery, St George's University Hospitals NHS Foundation Trust, London, United Kingdom \\ Corresponding Author: Fatma Nihal DURMUS KOCAASLANＥ-mail: dr-nihal@hotmail.com
}

Submitted: 28.07.2019 Accepted: 13.09.2019

\begin{abstract}
Objective: In this study, we aimed to evaluate residual tumors and recurrence rates of malignant melanoma (MM) and a nonmelanoma skin cancer of (NMSC) head and neck region.

Patients and Methods: Medical data of a total of 398 lesions of 323 patients who underwent surgical excision for a basal cell carcinoma (BCC), squamous cell carcinoma (SCC), and malignant melanoma (MM) were retrospectively analyzed. All patients were classified according to age, sex, location of the tumor, histopathological diagnosis, lesion diameter, excision diameter, surgical margin status, and residual lesions and recurrence rates.

Results: There were 244 lesions (61.3\%) in 189 males and 154 lesions (38.7\%) in 134 females. The most common type of skin cancer was BCC in 268 lesions (67\%), followed by SCC in 122 (31\%), and MM in eight (2\%), respectively. Recurrence was seen in $3 \%$ of the NMSC cases and in $25 \%$ of the MM cases. There was a statistically significant correlation between the histopathological diagnosis and recurrence rates. Compared to NMSC, MM cases had a higher risk for recurrence $(p=0.029)$.

Conclusion: Our study results suggest that recurrence is associated with the localization and type of the tumor, but not with the age or sex of the patient.

Keywords: Basal cell carcinoma, Squamous cell carcinoma, Malignant melanoma, Recurrence, Residual tumor
\end{abstract}

\section{INTRODUCTION}

Skin cancer is the leading cancer in the world [1]. In recent years, the incidence of the skin cancer has been increasing, although, the mortality rates still remain unchanged [2]. Skin cancer can be mainly divided into two groups as malignant melanoma (MM) and non-melanoma skin cancer (NMSC). There are two main subtypes of NMSC as basal cell carcinoma (BCC) in which cancer is derived from epidermal cells of the basal layer and squamous cell carcinoma (SCC) which originates from the malignant proliferation of the epidermal keratinocytes [3-5]. However, MM originates from the melanocytes which are the pigment-generating cells of the skin [6].

Basal cell carcinoma is the dominant form of skin cancer which accounts for $80 \%$ of all cases [7]. Due to its slow-growing and non-aggressive nature, metastasis is unlikely [8]. Although, BCC is not usually fatal, it may be associated with significant morbidities and complications due to its locally invasive nature [9]. As the other form of NMSC, SCC is the second most common type of skin cancer, accounting for $20 \%$ of all NMSC cases $[7,10]$. In contrast to BCC, SCC acts in a more aggressive manner with a higher metastasis risk $[11,12]$. The major factor for the development of NMSC is the cumulative exposure to ultraviolet radiation (UV) [13]. Consequently, the typical locations of NMSC are the areas of the skin which are regularly exposed to sun, such as head and neck region [14].

On the other hand, MM is the rarest form of skin malignancies, accounting for $1 \%$ of all skin cancer cases [15]. Although, MM is the least likely skin malignancy, it is associated with a high incidence of skin cancer-related mortality [16]. According to the American Cancer Society, MM is recognized as being the sixth most common cancer in the United States [17].

In the present study, we aimed to investigate the distribution of skin cancers of the head and neck and to evaluate the residual and recurrent cases.

\section{PATIENTS AND METHODS}

This retrospective study was conducted at Marmara University, Training and Research Hospital, Department of Plastic, Reconstructive and Aesthetic Surgery between January 2010

How to cite this article: Durmus Kocaaslan FN, Alakus AC, Sacak B, Celebiler O. Evaluation of residual tumors and recurrence rates of malignant melanoma and non-melanoma skin cancer of head and neck region. 2019; 32: 107-111. doi: 10.5472/marumj.637558 
and December 2015. This study included BCC, SCC, and MM cases of the head and neck region. The head and neck region were divided into eight subunits to obtain a systematic analysis of the retrieved data including the scalp, forehead, periauricular, periorbital, nose, cheek, perioral, and chin. In addition to benign tumors, tumors located in other areas, precursor lesions of the skin and rarer types of skin cancer (i.e., Merkel cell carcinoma, cutaneous lymphomas, Kaposi sarcoma, and skin adnexal tumors) were excluded.

Finally, a total of 1801 lesions underwent a surgical excision. After the pathology reports were classified for eligibility; 398 skin lesions of 323 patients were included in the study. Eligible cases were classified according to the age, sex, location of the tumor, histopathological diagnosis, lesion diameter, excision diameter, surgical margin status, and residual lesions and recurrence rates. A residual lesion was defined as the presence of cancer cells in the surgical margins after the initial excision. A recurrent lesion was defined as histopathological evidence of tumor in the same excision area after the initial excision.

A written informed consent was obtained from each patient. Ethical approval was obtained for the present study from Marmara University Ethical Committee (approval number: ......). The study was conducted in accordance with the principles of the Declaration of Helsinki.

\section{Statistical Analysis}

Statistical analysis was performed using the STATA 10.0 software (STATA Corp., College Station, TX, USA). Descriptive statistics were expressed in mean \pm standard deviation (SD), median (min-max), or number and frequency. The chi-square test was used to analyze statistically significant differences between the MM and NMSC groups. A p value of $<0.05$ was considered statistically significant.

\section{RESULTS}

A total of 398 skin lesions of 323 patients in the head and neck region were surgically excised. There were 244 lesions $(61.3 \%)$ in 189 males and 154 lesions (38.7\%) in 134 females. The maleto-female ratio was $1.41: 1$. The mean age of all patients was $66.3 \pm 15.55$ (range, 6 to 59 ) years. The most common type of skin cancer was BCC in 268 lesions (67\%), followed by SCC in 122 (31\%), and MM in eight (2\%), respectively. Following the initial excision, 333 cases (84\%) were successfully removed, while there were 59 procedures (15\%) resulting in tumor presence in the surgical margin. No data were available in six (2\%) of the excisions. Recurrence was seen in 14 cases (3.5\%) (Table I).

\section{Sex}

Among all excised BCC lesions, 152 (56.8\%) were removed from males and 116 (43.2\%) from females. A male dominance was observed in SCC in 86 procedures (70.5\%) among male patients, while 36 procedures $(29.5 \%)$ were performed in female patients. Of the total MM cases, six (75\%) were males and two (25\%) were females (Table I).

\section{Age}

The mean age was similar among BCC and SCC cases $(66.4 \pm 13.03$ years and $66.5 \pm 13.03$ years, respectively). The mean age of MM cases was $59.8 \pm 20.72$ years (Table I).

Table I. Demographic and clinical characteristics of patients

\begin{tabular}{|l|l|l|l|l|}
\hline & Total & BCC & SCC & MM \\
\hline Sex Male & $244(61.3 \%)$ & $152(57.8 \%)$ & $86(70.5 \%)$ & $6(75 \%)$ \\
\hline Female & $154(38.7 \%)$ & $116(43.2 \%)$ & $36(29.5 \%)$ & $2(25 \%)$ \\
\hline Tumor, n (\%) & $398(100 \%)$ & $268(67 \%)$ & $122(31 \%)$ & $8(2 \%)$ \\
\hline $\begin{array}{l}\text { Age, years, mean } \pm \text { SD } \\
\text { (range) }\end{array}$ & $\begin{array}{l}66.3 \pm 15.55 \\
(6 \text { to } 95)\end{array}$ & $\begin{array}{l}66.4 \pm 13.03 \\
(17 \text { to } 90)\end{array}$ & $\begin{array}{l}66.5 \pm 19.76 \\
(6 \text { to } 95)\end{array}$ & $\begin{array}{l}59.8 \pm 20.72 \\
(27 \text { to } 84)\end{array}$ \\
\hline $\begin{array}{l}\text { Surgical margin } \\
\text { status (+) }\end{array}$ & $59(15 \%)$ & $48(18 \%)$ & $11(9 \%)$ & 0 \\
\hline (-) & $333(84 \%)$ & $216(80.5 \%)$ & $109(89 \%)$ & $8(100 \%)$ \\
\hline Missing data & $6(2 \%)$ & $4(1.5 \%)$ & $2(2 \%)$ & 0 \\
\hline Recurrence, n $(\%)$ & $14(3.5 \%)$ & $8(3 \%)$ & $4(3 \%)$ & $2(25 \%)$ \\
\hline
\end{tabular}

BCC: basal cell carcinoma, SCC: squamous cell carcinoma, MM: malignant melanoma, SD: standard deviation

\section{Location and sex}

Most of the lesions were found in the nasal area in 111 cases $(27.8 \%)$, followed by the perioral area in 68 cases $(17.1 \%)$ and periorbital area in 65 cases $(16.3 \%)$. The rate of skin malignancies was the lowest in around the chin and forehead in only six (1.5\%) and $24(6 \%)$ cases, respectively. Skin cancer appeared in the nasal region most commonly in both sexes. A total of $20.9 \%$ of the excisions were carried out in males and $38.9 \%$ in females. Around the periauricular region, the figures were much higher in males in $15.6 \%$ of the male population $(n=38)$. On the other hand, only $0.8 \%$ of the female patients $(n=2)$ had cancer in this area (Table II).

Table II. Sex of patients and location of tumors according to groups

\begin{tabular}{|l|l|l|l|l|l|l|}
\hline & Total & M & F & BCC & SCC & MM \\
\hline Cheek & $\begin{array}{l}33 \\
(8.3 \%)\end{array}$ & $\begin{array}{l}18 \\
(7.4 \%)\end{array}$ & $\begin{array}{l}15 \\
(9.7 \%)\end{array}$ & $\begin{array}{l}21 \\
(7.8 \%)\end{array}$ & $8(6.5 \%)$ & $4(50 \%)$ \\
\hline Chin & $6(1.5 \%)$ & $2(0.8 \%)$ & $4(2.6 \%)$ & $3(1.1 \%)$ & $3(2.5 \%)$ & 0 \\
\hline Forehead & $24(6 \%)$ & $\begin{array}{l}16 \\
(6.5 \%)\end{array}$ & $8(5.2 \%)$ & $\begin{array}{l}17 \\
(6.3 \%)\end{array}$ & $7(5.7 \%)$ & 0 \\
\hline Nose & $\begin{array}{l}111 \\
(27.8 \%)\end{array}$ & $\begin{array}{l}51 \\
(20.9 \%)\end{array}$ & $\begin{array}{l}60 \\
(38.9 \%)\end{array}$ & $91(34 \%)$ & $\begin{array}{l}19 \\
(15.6 \%)\end{array}$ & $\begin{array}{l}1 \\
(12.5 \%)\end{array}$ \\
\hline Periauricular & $40(10 \%)$ & $\begin{array}{l}38 \\
(15.6 \%)\end{array}$ & $2(1.3 \%)$ & $\begin{array}{l}28 \\
(10.4 \%)\end{array}$ & $11(9 \%)$ & $\begin{array}{l}1 \\
(12.5 \%)\end{array}$ \\
\hline Perioral & $\begin{array}{l}68 \\
(17.1 \%)\end{array}$ & $\begin{array}{l}47 \\
(19.3 \%)\end{array}$ & $\begin{array}{l}21 \\
(13.6 \%)\end{array}$ & $\begin{array}{l}21 \\
(7.8 \%)\end{array}$ & $\begin{array}{l}47 \\
(38.5 \%)\end{array}$ & 0 \\
\hline Periorbital & $\begin{array}{l}65 \\
(16.3 \%)\end{array}$ & $\begin{array}{l}38 \\
(15.6 \%)\end{array}$ & $\begin{array}{l}27 \\
(17.5 \%)\end{array}$ & $\begin{array}{l}50 \\
(18.6 \%)\end{array}$ & $\begin{array}{l}14 \\
(11.5 \%)\end{array}$ & $\begin{array}{l}1 \\
(12.5 \%)\end{array}$ \\
\hline Scalp & $\begin{array}{l}51 \\
(12.8 \%)\end{array}$ & $\begin{array}{l}34 \\
(13.9 \%)\end{array}$ & $17(11 \%)$ & $\begin{array}{l}37 \\
(13.8 \%)\end{array}$ & $\begin{array}{l}13 \\
(10.7 \%)\end{array}$ & $\begin{array}{l}1 \\
(12.5 \%)\end{array}$ \\
\hline Total & 398 & 244 & 154 & 268 & 122 & 8 \\
\hline
\end{tabular}

Data are given in number and percentage. M: male; F: female, BCC: basal cell carcinoma, SCC: squamous cell carcinoma, MM: malignant melanoma 


\section{Surgical margins}

A total of 216 (80.5\%) of 268 BCC cases were excised successfully, while in 48 cases (18\%), there was a tumor presence in the surgical margins. Among 122 SCC cases, 109 (89\%) were excised adequately and $11(9 \%)$ were inadequately removed. All residual lesions were re-excised and clear margins were established. No inadequate margin was detected after the initial excision of all MM cases. There were missing data in six of the cases (Table III).

Table III. Margin status according to subunits

\begin{tabular}{|l|l|l|l|l|}
\hline & \multicolumn{3}{|c|}{ Margin Status } & \\
\hline Cheek & Negative & Positive & Missing data & Recurrence \\
\hline Chin & $28(8.4 \%)$ & $4(6.7 \%)$ & 1 & 0 \\
\hline Forehead & $4(1.2 \%)$ & $1(1.7 \%)$ & 1 & 0 \\
\hline Nose & $22(6.6 \%)$ & $1(1.7 \%)$ & 1 & $2(14.3 \%)$ \\
\hline Periauricular & $91(27.3 \%)$ & $\mathbf{2 0 ( 3 3 . 9 \% )}$ & 0 & $\mathbf{6 ( 4 2 . 9 \% )}$ \\
\hline Perioral & $32(9.6 \%)$ & $7(11.9 \%)$ & 1 & $1(7.1 \%)$ \\
\hline Periorbital & $59(17.7)$ & $8(13.5 \%)$ & 1 & $2(14.3 \%)$ \\
\hline Scalp & $52(15.6 \%)$ & $12(20.3 \%)$ & 1 & 0 \\
\hline Total & $45(13.5 \%)$ & $6(10.2 \%)$ & 0 & $3(21.4 \%)$ \\
\hline
\end{tabular}

Data are given in number and percentage.

\section{Recurrence rates}

Recurrence was seen in a total of 3\% of the NMSC cases (3\% of BCC lesions, $n=8$ and $3 \%$ of SCC lesions, $n=4$ ), while this rate was $25 \%$ in the MM cases. There was a statistically significant correlation between the histopathological diagnosis and recurrence rates. Compared to NMSC, MM cases had a higher risk for recurrence $(\mathrm{p}=0.029)$, even a clear margin was achieved in all MM cases. All recurrent cases were excised and clear margins were achieved (Table IV).

Table IV. Margin status after recurrence

\begin{tabular}{|l|l|l|l|}
\hline & \multicolumn{2}{|c|}{ Margin Status } \\
\hline BCC & Negative & Positive & n \\
\hline SCC & 8 & 0 & 8 \\
\hline MM & 4 & 0 & 4 \\
\hline Total & 2 & 0 & 2 \\
\hline
\end{tabular}

BCC: basal cell carcinoma, SCC: squamous cell carcinoma, MM: malignant melanoma

\section{DISCUSSION}

Basal cell carcinoma is the most common type of skin cancer in Caucasians, which predominantly occurs in the exposed parts of the body, with $80 \%$ of the lesions found in the head and neck regions [18]. Our study results also showed that most of the lesions were found in the nose $(27.8 \%)$, perioral $(17.1 \%)$, and periorbital $(16.3 \%)$ regions, which are the most prominent parts exposed to chronic sun radiation, and also in the $\mathrm{H}$ area.
In the literature, most of the BCC lesions are reported in the 4079 age group with a mean age of 62 years. However, in tropical regions and in patients with a family history, BCC may occur in a younger age $[19,20]$. In our study, the mean age of BCC cases was 66.4 (range, 17 to 90 ) years with a statistically significant increase in the $60-70$ and $70-80$ age groups $(28.9 \%$ and $27.6 \%$, respectively). Also, in the other Mediterranean countries, it mostly affects the 70-80 age group [21-24]. Our study results regarding the age of the patients and location of the lesions were consistent with the literature.

Previous studies have demonstrated a higher rate of BCC in male patients [25-27]. In our study, there was no statistically significant difference between men (57\%) and women (43\%), that was consistent with previous studies $[22,25,28]$. According to the subunits, nose (20.9\%), perioral (19.3\%), periorbital (15.6\%), periauricular (15.6\%), and scalp (13.9\%) involvement were more common in male patients. Nose (38.9\%), periorbital $(11 \%)$, and perioral $(8.6 \%)$ involvement were more common in female patients. These can be attributed to the fact that urban life affects both sexes equally. Periauricular BCC was seen in only two female patients $(0.8 \%)$, compared to male patients, which can be explained by the possible protective effect of scarf wearing in women.

The main goals of the tumor treatment are to eradicate the tumor with the safest and most cost-effective method available and to provide an aesthetically and functionally satisfactory outcome. Although, different treatment modalities for BCC have been described in the literature, surgical excision is the most effective and commonly adapted method for tumor removal [27].

In the literature, a $3-\mathrm{mm}$ peripheral surgical margin is adequate for the clearance of $85 \%$ of small and well-defined BCCs, and the 4 to 5 - $\mathrm{mm}$ margin would raise this figure to $95 \%$ [29]. This margin is $1 \mathrm{~cm}$ for SCCs and 1 to $2 \mathrm{~cm}$ for MMs, depending on the tumor depth [8]. In our study, BCCs were excised with a 3 to $5-\mathrm{mm}$ clear margin, depending on the location of the tumor, while SCCs were excised with a $1-\mathrm{cm}$ clear margin and MMs were excised with a 2-cm clear margin. Previous studies have shown a great variability in the re-excision rates ranging from $9 \%$ to $75 \%$ for BCCs [30]. In our study, the rate of residual tumors resulting in re-excision was $18 \%$ for BCCs, $9 \%$ for SCCs, and $0 \%$ for MMs. This relatively high rate may result from the fact that BCCs were seen around the aesthetic subunits such as nose, eyelid, and lip and there may be an effort to keep the excision margin narrow not to compromise the cosmetic results. The majority of the studies showed that BCC and SCC required a similar number of stages to obtain free margins, although some authors suggested that BCC required more stages than SCC, which was consistent with our findings [31-34]. The fewer stages required to obtain clear margins in SCC than in BCC may be due to the more aggressive behavior of the primary tumor, leading to extreme caution, and the consequent removal of more peripheral tissues per stage. Another possible explanation is that SCCS are better defined on clinical examination [35].

Review of the literature reveals that the recurrence rate for primary BCCs after surgical excision varies between $5 \%$ and $14 \%[29,36]$. Lesions in the head and neck region are at a higher 
risk for recurrence, compared to lesions in the trunk and limbs [29,36-38]. Incomplete excision has been also reported as one of the risk factors for recurrence [25,39-41]. In our series, the overall recurrence rate was $3 \%$ for NMSC $(n=8$ BCC and $n=4$ SCC) and 25\% for MM (n=2). Recurrent lesions were located in the nose $(n=6)$, scalp $(n=3)$, forehead $(n=2)$, perioral $(n=2)$, and periauricular $(n=1)$ regions. The recurrence rate $(2 / 8,25 \%)$ seems relatively high, although this can be explained by the small number of the overall MM cases in our study. However, there was no residual tumor after MM excision in two recurrent cases. This is probably due to the aggressive behavior of MM. More interestingly, most recurrences were located in the $\mathrm{H}$ area which can be attributed to high recurrence rates on the embryonic fusion planes and also close margin excision tendency not to harm the aesthetic subunits [27,42-44].

Previous studies have shown a reduced residual rate of BCCs through Mohs microscopic surgery or a margin-controlled, staged surgical excision in institutions where Mohs surgery is not available [45]. In particular, in the $\mathrm{H}$ area where the recurrence risk is high and aesthetic subunits of the face are included, a staged surgical excision is superior to simple excision.

Nonetheless, there are some limitations to this study. Retrospective design with a relatively small sample size is the main limitation. In addition, all operations were performed by residents and specialists. Although resections were done in accordance with the current guidelines, considering the fact that learning curve may vary for each surgeon, the results might have been different for surgeons, indicating variability in surgical outcomes. Therefore, further large-scale, prospective studies are warranted.

In conclusion, our study results suggest that recurrence is associated with the localization of the tumor, but not with the age, sex, and type of the tumor. Of note, it should be kept in mind that the low recurrence rates in our series may be due to the excision with an appropriate margin and no positive surgical margins after second surgery. However, further large-scale, prospective studies are needed to establish a definite conclusion.

Funding: The study was not supported by any funds.

Conflict of interest: The authors have no conflicts of interest to declare.

\section{REFERENCES}

[1] Scarabello A, Muti P. Epidemiology and prevention of cutaneous tumors. In: Baldi A, Pasquali P, Spugnini E P, eds. Skin Cancer: A Practical Approach. New York: Humana Press, 2014: 17-28. doi: 10.1007/978-1-4614-7357-2_2

[2] Guy Jr GP, Thomas CC, Thompson T, Watson M, Massetti G.M, Richardson LC; Centers for Disease Control and Prevention (CDC). Vital signs: melanoma incidence and mortality trends and projections - United States, 1982-2030. MMWR - Morb Mortal Wkly Rep 2015: 64:591-6.

[3] Gillard M, Wang T S, Johnson TM. Nonmelanoma cutaneous malignancies. In: Chang AE, Ganz PA, Hayes DF, et al., eds.
Oncology: An Evidence-Based Approach. New York: Springer, 2006: 1102-18.

[4] Jacobs GH, Rippey JJ, Altini M. Prediction of aggressive behavior in basal cell carcinoma. Cancer 1982;49:53-7. doi: 10.1155/2011/496910.

[5] Thieu K, Ruiz M, Owens DM. Cells of origin and tumorinitiating cells for nonmelanoma skin cancers. Cancer Lett 2013;338:82-8. doi: 10.1016/j.canlet.2012.05.008.

[6] Shashanka R, Smitha BR. Head and Neck Melanoma. ISRN Surgery 2012, Article ID 948302. doi: 10.5402/2012/948302.

[7] Kwa RE, Campana K, Moy RL. Biology of cutaneous squamous cell carcinoma. Am Acad Dermatol 1992; 26:1-26.

[8] Ouyang Y H. Skin cancer of the head and neck. seminars in Plastic Surgery. Semin Plas Surg 2010;24:117-26. doi: 10.1055/ s-0030.125.5329.

[9] Leiter U, Eigentler T, Garbe C. Epidemiology of skin cancer. Adv Exp Med Biol 2014; 810:120-40.

[10] Johnson TM, Rowe DE, Nelson BR, Swanson NA. Squamous cell carcinoma of the skin (excluding lip and oral mucosa). J Am Acad Dermatol 1992; 26:467-84.

[11] Alam M, Ratner D. Cutaneous squamous-cell carcinoma. N Engl J Med 2001;344: 97-983

[12] Padgett JK, Hendrix J D, Jr. Cutaneous malignancies and their management. Otolaryngol Clin North Am 2001;34:523-53.

[13] Fears TR, Scotto J. Estimating increases in skin cancer morbidity due to increases in ultraviolet radiation exposure. Cancer Invest 1983;1:119-26.

[14] Scotto J, Fears TR, Fraumeni JF. Incidence of nonmelanoma skin cancer in the United States. NIH Pub No: 83-2433. Bethesda, MD: U.S. Department of Health and Human Services. 1983.

[15] Hasan Z, Riffat F. Epidemiology and aetiology of nonmelanoma skin cancer. In: Riffat F, Palme CE, Venesss M, editors. Non-Melanoma Skin Cancer of the Head and Neck. New Delhi: Springer, 2015: 1-9. doi: 10.1007/978-81-3222497-6

[16] Lai V, Cranwell W, Sinclair R. Epidemiology of skin cancer in the mature patient. Clin Dermatol 2018;36:167-76. doi:10.1016/j.clindermatol.2017.10.008.

[17] Marks R. An overview of skin cancers. Incidence and causation. Cancer 1995;75:607-12.

[18] Demirseren DD, Ceran C, Aksam B, Demirseren ME, Metin A. Basal cell carcinoma of the head and neck region: A retrospective analysis of completely excised 331 cases. J Skin Cancer 2014;2014:858636. doi: 10.1155/2014/858636.

[19] Tiftikcioğlu YO, Karaaslan O, Aksoy HM, Aksoy B, Koc U. Basal cell carcinoma in Turkey. The Journal of Dermatology 2006; 33: 91-95.

[20] Rippey JJ. Why classify basal cell carcinomas? Histopathology 1998:32,: 393-8.

[21] Gloster HM. Jr. Neal K. Skin cancer in skin of color. J Am Acad Dermatol 2006;55:741-doi: 10.1016/j.jaad.2005.08.063 
[22] Betti R, Inselvini E, Carducci M, Crosti C. Age and site prevalence of histologic subtypes of basal cell carcinomas. Int J Dermatol 1995;34;174-6.

[23] Boi S, Cristofolini M, Micciolo R, Polla E, Palma PD. Epidemiology of skin tumors: data from the cutaneous cancer registry in Trentino, Italy. J Cutan Med Surg 2003;7:300-5. doi: 10.1007/s10227.002.0135-0

[24] Revenga AF, Paricio R J F, Vazquez S M M, del Villar S V. Descriptive epidemiology of basal cell carcinoma and cutaneous squamous cell carcinoma in Soria (north-eastern Spain) 1998-2000: a hospital-based survey. J Eur Acad Dermatol Venereol 2004;18:137-41.

[25] Seretis K, Thomaidis V, Karpouzis A, Tamiolakis D, Tsamis I. Epidemiology of surgical treatment of nonmelanoma skin cancer of the head and neck in Greece. Dermatol Surg 2010;36;15-22. doi: 10.1111/j.1524-4725.2009.01379.x.

[26] Scrivener Y, Grosshans E, Cribier B. Variations of basal cell carcinomas according to gender, age, location and histopathological subtype. Br J Dermatol 2002 ;147:41-7.

[27] Soyer HP, Rigel DS, Wurm EMT. Actinic keratosis, basal cell carcinoma and squamous cell carcinoma in Dermatology. In: Bolognia JL, Jorizzo JL, Schaffer JV, eds. Beijing, China: Elsevier Saunders, 2012:1773-93.

[28] Czarnecki D, Collins N, Meehan C, O’Brien T, Leahy S, Nash C. Basal-cell carcinoma in temperate and tropical Australia. Int J Can 1992; 50: 874-5.

[29] Janjua OS, Qureshi SM. Basal cell carcinoma of the head and neck region: ananalysis of 171 cases. J Skin Can 2012;2012:943472. doi: 10.1155/2012/943472.

[30] Masud D, Moustaki M, Staruch R, Dheansa B. Basal cell carcinomata: Risk factors for incomplete excision and results of re-excision. J Plast Reconstr Aesthet Surg 2016;69:652-6. doi: 10.1016/j.bjps.2015.12.024.

[31] Diepgen TL, Mahler V. The epidemiology of skin cancer. Br J Dermatol 2002;146: 1-6.

[32] Schell AE, Russell MA, Park SS. Suggested excisional margins for cutaneous malignant lesions based on Mohs micrographic surgery. JAMA Facial Plast Surg 2013;15:337-43. doi: 10.1001/ jamafacial.2013.1011.

[33] Batra RS, Kelley LC. Predictors of extensive subclinical spread in non-melanoma skin cancer treated with Mohs micrographic surgery. Arch Dermatol 2002;138:10451.
[34] Alam M, Berg D, Bhatia A, et al. Association between number of stages in Mohs micrographic surgery and surgeon, patient, and tumor-specific features: a cross-sectional study of practice patterns of 20 early and mid-career Mohs surgeons. Dermatol Surg 2010;36:1915-20.

[35] Delgado Jiménez Y, Camarero-Mulas C, Sanmartín-Jiménez $\mathrm{O}$, et al. Differences of Mohs micrographic surgery in basal cell carcinoma versus squamous cell carcinoma. Int J Dermatol $2018 ; 57: 1375-81$. doi: 10.1111/ijd.14223.

[36] Sartore L, Lancerotto L, Salmaso M, et al. Facial basal cell carcinoma: analysis of recurrence and follow-up strategies. Oncol Rep 2011;26:1423-9. doi: 10.3892/or.2011.1453.

[37] Smith V, Walton S. Treatment of facial basal cell carcinoma: a review. Journal of Skin Cancer 2011, Article ID 380371 doi: 10.1111/j.1524-4725.2010.01758.x.

[38] Sussman LAE, Liggins D F. Incompletely excised basal cell carcinoma: a management dilemma? Aust N Z J Surg 1996;66:276-8. doi: 10.1111/j.1445-2197.1996.tb01184.x

[39] Farhi D, Dupin N, Palangie A, Carlotti A, Avril MF. Incomplete excision of basal cell carcinoma: rate and associated factors among 362 consecutive cases. Dermatol Surg 2007;33:120714.

[40] Griffiths RW, Suvarna SK, Stone J. Basal cell carcinoma histological clearance margins: an analysis of 1539 conventionally excised tumors. Wider still and deeper? J Plast Reconstr Aesthet Surg 2007 ;60:41-7.

[41] Griffiths R W, Suvarna S K, Stone J. Do basal cell carcinomas recur after complete conventional surgical excision? Br J Plast Surg 2005;6:795-805.

[42] Goh BK, Ang P, Wu YJ, Goh CL. Characteristics of basal cell carcinoma amongst Asians in Singapore and a comparison between completely and incompletely excised tumors. Internat J Dermatol 2006;45: 561-4.

[43] Richmond JD, Davie RM. The significance of incomplete excision in patients with basal cell carcinoma. Br J Plast Surg 1987;40:63-7.

[44] Goldberg DP. Assessment and surgical treatment of basal cell skin cancer. Clin Plast Surg 1997;24: 673 - 86.

[45] Durmus Ucar AN, Durmus Kocaaslan FN, Salman A, Demirkesen C, Erdem Bayram F, Bayramicli M. Margincontrolled, staged surgical excision in the treatment of highrisk basal cell carcinomas of the head and neck region. J Cutan Med Surg 2019;23:258-64. doi: 10.1177/120.347.5418820868. 